\title{
Investigating Land-Use Change on Street Tree Ecosystems
}

\author{
Thomas Turnbull1', Sharon Jean-Philippe', Raymond Albright'1, David Buckley, \\ Sean Schaeffer ${ }^{2}$, P. Eric Wiseman ${ }^{3}$ \\ ${ }^{1}$ Department of Forestry, Wildlife and Fisheries, University of Tennessee, Knoxville, US \\ ${ }^{2}$ Department of Biosystems Engineering and Soil Science, University of Tennessee, Knoxville, US \\ ${ }^{3}$ Department of Forest Resources \& Environmental Conservation, Virginia Tech, Blacksburg, US \\ Email: tturnbul@vols.utk.edu, jeanphil@utk.edu, ralbright@utk.edu, dbuckley@utk.edu, sschaef5@utk.edu, \\ pwiseman@vt.edu
}

Received 22 July 2014; revised 25 August 2014; accepted 4 September 2014

Copyright (C) 2014 by authors and Scientific Research Publishing Inc.

This work is licensed under the Creative Commons Attribution International License (CC BY). http://creativecommons.org/licenses/by/4.0/

(c) (i) Open Access

\section{Abstract}

In the early 1940's, during the early stages of the Manhattan Project (WWII), of rural communities in Anderson County, Tennessee was rapidly converted into laboratory facilities and the city of Oak Ridge. The environment that became Oak Ridge experienced not only pollutants from the laboratory activities, but also alterations from the land-use change from rural to urban areas. Therefore, a study was conducted to determine the impacts of land-use change from rural to urban area on 1) street tree diversity and performance; and 2) the biological, chemical and physical properties, and nutrient dynamics of street tree ecosystem soils. There were a total of 607 street trees, composed of 37 different species, on the five main roadways in Oak Ridge, Tennessee. The street tree inventory revealed that the street tree ecosystems had a high relative abundance of Acer rubrum (21.91\%) and Pyrus calleryana (19.93\%). Chemical, rather than physical, soil and site properties in street tree ecosystems had the greatest impact on street tree performance. Soils differed street by street in their biological, chemical, and physical properties but were not influenced by traffic rates. There were also differences in soil microbial biomass carbon (MBC) during the winter on streets based on their diversity of trees; however, the most diverse street was among the lowest in soil microbial biomass. Seasonally, the winter proved to have not only greater amounts of soil microbial biomass carbon and nitrogen (MBN), but significantly less extractable organic carbon (EOC) and nitrogen (EON) and total labile carbon (TLC) than that in the spring. Overall, this study provided insights into the post urbanization impacts on the street trees, soils, sites, and nutrient dynamics within street tree ecosystems of Oak Ridge.

\section{Keywords}

Street Trees, Soil Microbial Carbon, Soil Microbial Nitrogen, Tree Condition, Urban Forestry, Urban Soils 


\section{Introduction}

Urban trees (street trees, park trees, residential trees, etc.) face a host of environmental stressors such as pests, diseases, harsh climatic conditions, and poor soil qualities (Miller, 1997). Trees in more natural or rural settings are still exposed to many environmental factors such as pests or climatic conditions, but urban trees must be able to withstand natural stressors as well as issues associated more closely with an urban environment (Miller, 1997). The proximity of street trees to construction activities has been found to greatly impact the survival of street trees. These construction sites alter urban soils through compaction, chemical contamination, water saturation or depravation, and altered nutrient cycles, all of which can impact the ability for trees to thrive (Day et al., 2010; Tomiczek, 2003; Nielson et al., 2007). Hauer et al. (1994) found 5\% greater mortality of street trees adjacent to construction activities, and also that there was a significant positive correlation between street tree conditions and tree lawn widths (the area in which street trees are growing). Impervious surfaces play a large role in the ecosystem processes in an urban environment (Nowak and Greenfield, 2012). Most notably, impervious surfaces increase local temperature, thereby creating an urban heat island (UHI) that affects the hydrology, pollutant emissions, and ozone production (Heisler and Brazel, 2010; U.S. EPA, 1983; National Research Council, 2008). The hydrological impacts on street trees range from excessive amounts of water to completely devoid water. Street trees that are planted in poorly drained soils are at risk of oxygen deficiencies due to the flooding of the root zone (Saebo et al., 2003). On the other hand, Nielson et al. (2007) suggests that street tree planting pits can be totally depleted of soil water during the growing season due to poor water retention in tree pit soils. The lack of water available to street trees is also due to the size of a planting pit, rainfall interception by buildings, other impervious surfaces, the actual tree, and increased rates of evapotranspiration from the heat island (Lemaire and Rossignol, 1999; Tomiczek, 2003).

In 1942, during WWII, laboratories were built in East Tennessee whose purpose was to develop the uranium bomb (DOE, 2013). The rural forests and farmland that were in that area were rapidly converted into laboratory facilities and the City of Oak Ridge (Resen, 2010). The environment that became Oak Ridge not only experienced the pressures that came with land-use change from rural to urban, but also the inputs of excess heavy metals and toxic chemical wastes from the laboratory activities. Pollutants from the laboratory have also been found in streams that are adjacent to roadways within the city itself; therefore, the trees and soils that are in close proximity to the highly polluted streams may be impacted by the wastes from the laboratory facilities (JeanPhilippe et al., 2011). Since the environment has gone through so much disturbance and change, it is important to determine how the vegetation and soils have been impacted by the land-use change.

Knowledge about the diversity of street tree ecosystems and the performance of street trees in Oak Ridge could help determine how resilient the street tree ecosystems are to current pressures within the city, as well as the potential threats posed by pests and disease. Furthermore, knowledge about the soils within the street tree ecosystems could offer insight as to how street tree ecosystems have been impacted by land-use change from rural to urban area in their biological, chemical, and physical properties as well as nutrient cycling. We investigated the impacts of land-use change on established street trees and their soils environment. A field study was conducted in the City of Oak Ridge, Tennessee in order to determine the impacts of land-use change on street tree diversity, performance, site and soil biological, chemical and physical properties, and nutrient dynamics within street tree ecosystems.

\section{Methods}

\subsection{Site Description}

Oak Ridge, Tennessee is located in Anderson county of East Tennessee, USA (Figure 1). The city covers around $220.80 \mathrm{~km}^{2}$ with a population of approximately 29,351 people (US Census Bureau, 2012). Oak Ridge has an annual average precipitation of $129.31 \mathrm{~cm}$ and the growing season for the area spans 220 days (NOAA 2014; Tennessee Climatological Service). The streets that were used as the study sites were determined by the City of Oak Ridge Recreation \& Parks Department. The streets that were selected were the five main streets that intersect the city: Illinois Avenue 3.09 km (SW-NW), Rutgers Avenue $1.50 \mathrm{~km}(\mathrm{~S}-\mathrm{N})$, Tulane Avenue $0.80 \mathrm{~km}(\mathrm{~S}-\mathrm{N})$, Lafayette Avenue $2.40 \mathrm{~km}(\mathrm{~S}-\mathrm{N})$, and Oak Ridge Turnpike $9.25 \mathrm{~km}$ (SW-NE). The beginnings of each of the streets are found at the following coordinates: Illinois Avenue (-84 14.686, 36 0.11), Rutgers Avenue (-84 15.073, 36 0.332), Tulane Avenue (-84 15.416, 36 0.429), Lafayette Avenue (-84 14.534, 36 0.196), and Oak 


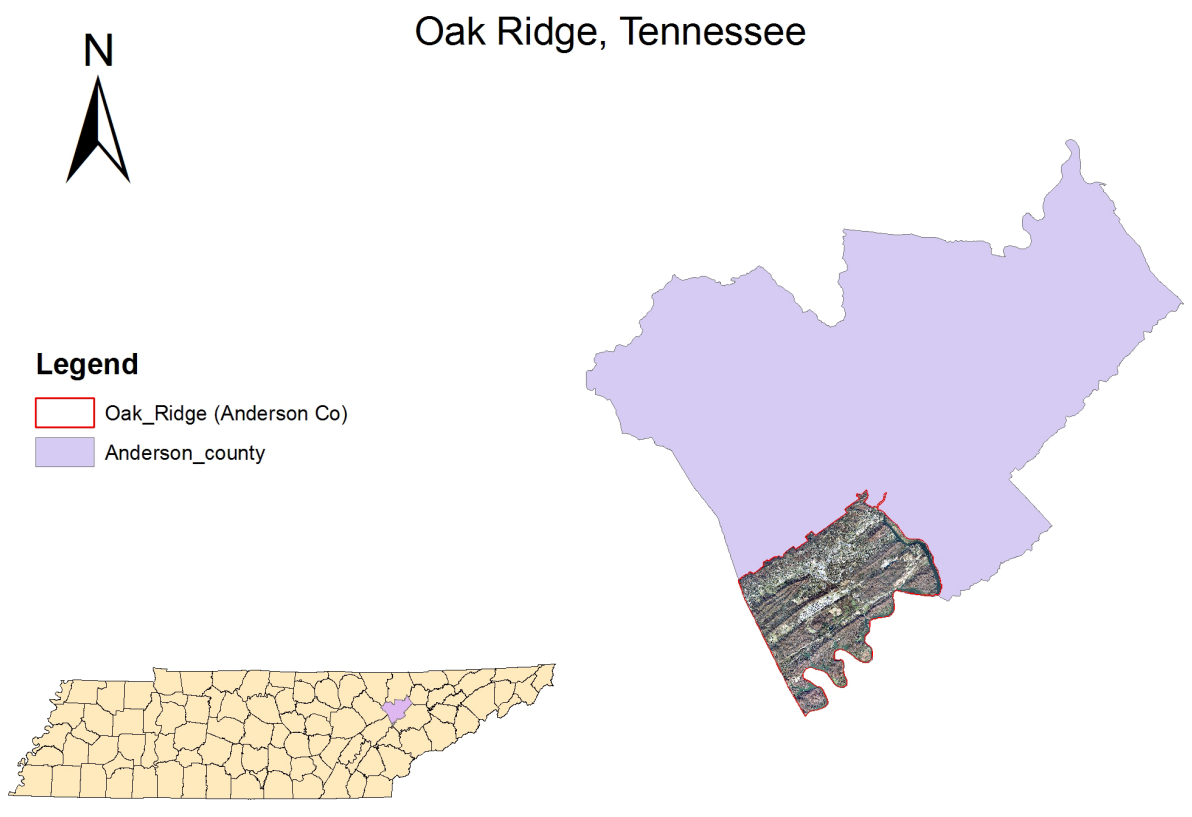

Figure 1. The city of Oak Ridge, Tennessee in Anderson County.

Ridge Turnpike (-84 12.419, 36 2.99). All roadways had two traffic lanes with the exception of Illinois Avenue, which had three lanes of traffic from its intersection with Lafayette to its intersection with Tulane before it decreased to two lanes. Along these five streets, the street trees were inventoried and random plots were generated for soil sampling (Figure 2). The dominant forest cover type in Anderson County is oak-hickory (Renewable Resources Evaluation Research Work Unit, 1982). The general soil environment found in the city of Oak Ridge is Collegedale-Gladeville-Rock Outcrop (USDA, 1981). Along the inventoried thoroughfares; the dominant soil types are Collegedale clays. Other soil types are Collegedale-rock outcrops, Upshur Variant silt clay loam, Hamblen silt loam, and Capshaw silt loam; however, the Collegedale clays are most abundant along the study sites (USDA, 1981). The five streets intersect the city's various industrial establishments and residential areas. Illinois, Tulane, Rut gers, and Oak Ridge Turnpike are characterized mainly by the many business establishments lining their edges. Lafayette Avenue also has industrial areas, but proportionally contains more residential areas than the other streets.

\subsection{Street Tree Inventory}

All live trees, dead trees, and stumps that were within the public right-of-way were included in the total inventory of the five main streets. The stumps and dead trees were included in the inventory for the Oak Ridge Recreation \& Parks Department to utilize at their own discretion in future management. Species name, diameter at breast height (dbh), geographic coordinates, and tree condition (good, fair, poor, dead) were recorded for each street tree that had a dbh of $2.54 \mathrm{~cm}$ or greater. A Garmin etrex 20 hand-held GPS was used with the mark waypoint feature to assign each tree and stump with latitudinal and longitudinal coordinates. To assess the health of The City of Oak Ridge street tree ecosystems a 25\% (152 street trees) random sample of live trees was selected from the total street tree inventory. Each of the 152 street trees was treated as a separate study plot. However, the sample size decreased to 136 street trees due to the removal of trees for maintenance or development purposes. The percentage of street trees from the random sample compared to the total amount of street trees along each street was $32 \%$ for Illinois, $42 \%$ for Rutgers, $15 \%$ for Tulane, $25 \%$ for Lafayette, and $23 \%$ for ORTP. The distance of each street tree to the nearest impervious surface was measured in order to determine the confinement of each planting space. To assess tree condition, Scharenbroch and Catania (2012) cumulative score ranking for different tree characteristics were adopted (Table 1). In order to measure annual twig elongation, the average length of the previous year's growth for four twigs (one for each cardinal direction) was used for each study street tree. When the canopy was too high to reach measurable twigs, a pole saw was used to cut twigs for those measurements. The crown width of each sample tree was also measured for another tree condition variable. 


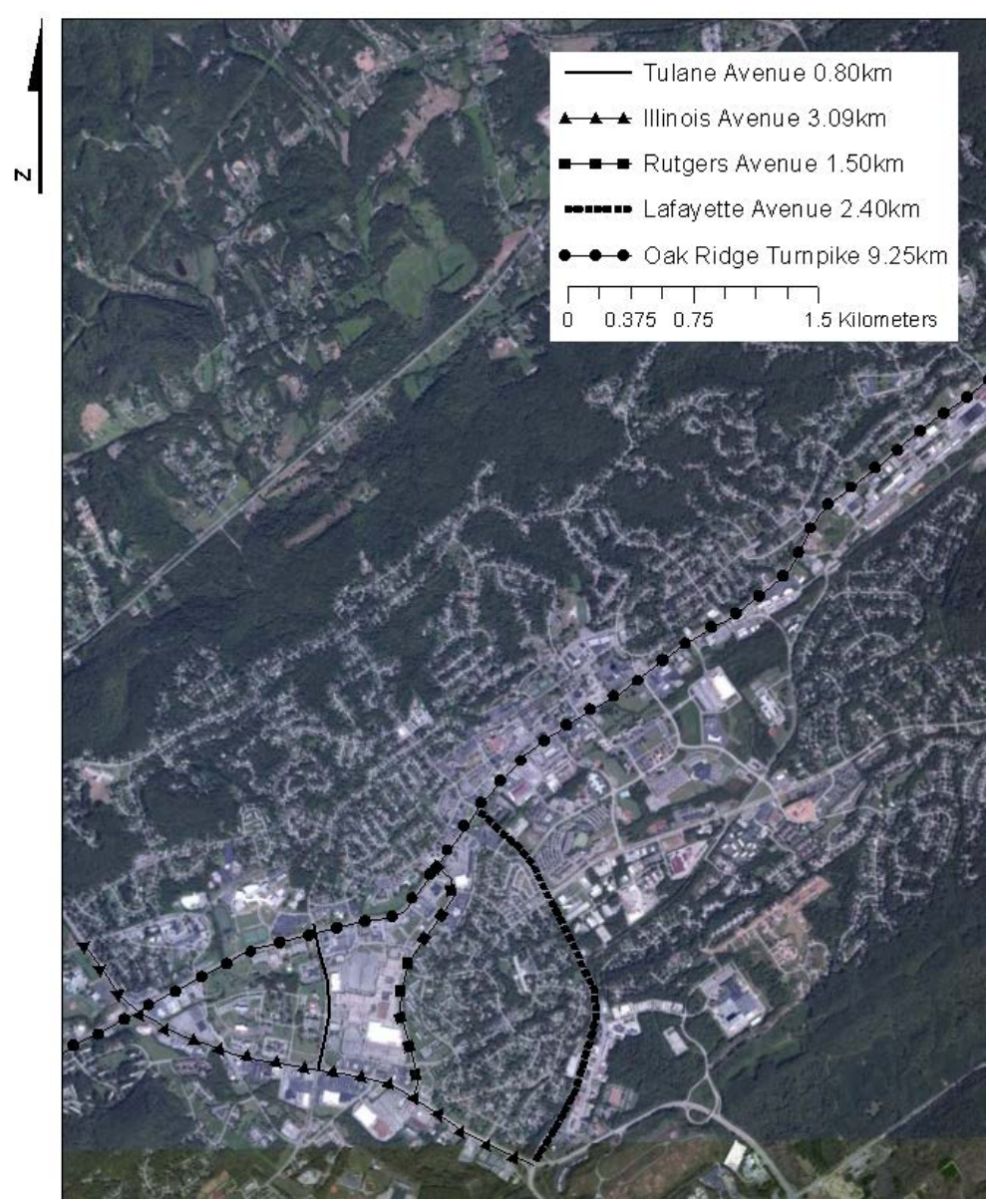

Figure 2. Soil sampling were randomly generated alonf these five street in the City of Oak Ridge, Tennessee.

Live crown ratio (LCR), expressed as a percentage (\%) was also determined for each of the sample street trees to be used as an additional condition variable. A three person consensus was used for determining tree score, tree crown width, and LCR.

\subsection{Tree Diversity Sampling}

Shannon's diversity index was calculated for the total inventory, and each street utilizing the calculation below:

$$
H_{i=1}^{\prime}=\sum(P i * \ln P i)
$$

where $\mathrm{Pi}=$ the relative abundance of each tree species found at each site, $\mathrm{S}=$ number of tree species found, and $\sum=$ sum of tree species 1 to species S (Shannon and Weaver, 1949). For the Oak Ridge street tree diversity calculations, five $100 \mathrm{~m}$ long transects were randomly generated along each street. Based on the random transects, all of the trees that were perpendicular to or bisected by each transect were used in the diversity calculations.

\subsection{Soil Sampling}

To assess seasonal variation in street tree ecosystem soils, soil samples were taken both in the winter of 2013 (2/25/2013-3/15/2013) and spring of 2013 (5/9/2013-5/28/2013) within the drip line of each study street tree. Six $2.5 \mathrm{~cm}$ diameter soil cores 20 - $30 \mathrm{~cm}$ deep were taken randomly; from which a composite sample was produced for each study plot. Soil samples then were bagged, labeled and stored at $-80^{\circ} \mathrm{C}$ until analyzed. Subsamples were taken from composite soil sample for all soil analyses. 
Table 1. Method for calculating cumulative tree condition scores for study street trees. Adapted from Scharenbroch and Catania (2012).

\begin{tabular}{|c|c|c|c|c|c|}
\hline \multirow[t]{2}{*}{ Factor } & \multicolumn{5}{|c|}{ Score } \\
\hline & 5 & 4 & 3 & 2 & 1 \\
\hline Trunk & $\begin{array}{l}\text { Sound and solid } \\
\text { throughout }\end{array}$ & Minor damage & Early decay signs & $\begin{array}{c}\text { Extensive decay, } \\
\text { hollowness cambium } \\
\text { damage }\end{array}$ & $\begin{array}{l}\text { Same as two, but } \\
\text { cross-section is a half circle }\end{array}$ \\
\hline Crown & $\begin{array}{l}\text { Dense, evenly } \\
\text { balanced crown }\end{array}$ & $\begin{array}{c}\text { Dense, slightly } \\
\text { unbalanced crown }\end{array}$ & $\begin{array}{l}\text { Thin or severely } \\
\text { imbalanced crown }\end{array}$ & $\begin{array}{l}\text { Thin and slightly } \\
\text { imbalanced crown }\end{array}$ & $\begin{array}{l}\text { Thin and severely } \\
\text { imbalanced crown }\end{array}$ \\
\hline Root & $\begin{array}{l}\text { Three or more evenly } \\
\text { balanced root flares }\end{array}$ & $\begin{array}{c}\text { Three or more } \\
\text { slightly unbalanced } \\
\text { root flares }\end{array}$ & $\begin{array}{l}\text { Less than three or } \\
\text { severely unbalanced } \\
\text { root flares }\end{array}$ & $\begin{array}{l}\text { No root flares \& } \\
\text { structural root } \\
\text { (2 to } 15 \mathrm{~cm} \text { deep) }\end{array}$ & $\begin{array}{l}\text { Structural roots } \\
\text { (>15 cm deep) }\end{array}$ \\
\hline Structure & $\begin{array}{l}\text { No major limbs missing, } \\
\text { broken, or dead no } \\
\text { narrow crotches; good } \\
\text { radial distribution }\end{array}$ & $\begin{array}{l}\text { Narrow crotch } \\
\text { on a } \\
\text { major limb }\end{array}$ & $\begin{array}{l}\text { One of major limbs } \\
\text { is dead or broken }\end{array}$ & $\begin{array}{c}\text { Two or three major limbs } \\
\text { with narrow crotches } \& \\
\text { one broken or dead } \\
\text { major limb }\end{array}$ & $\begin{array}{l}\text { Two or three major limbs } \\
\text { with narrow crotches } \& \\
\text { broken or dead major limbs }\end{array}$ \\
\hline Growth & $\begin{array}{l}>15 \mathrm{~cm} \text { annual twig } \\
\text { elongation }\end{array}$ & $\begin{array}{l}10 \text { - } 15 \mathrm{~cm} \text { annual } \\
\text { twig elongation }\end{array}$ & $\begin{array}{c}5 \text { - } 10 \mathrm{~cm} \text { annual twig } \\
\text { elongation }\end{array}$ & $\begin{array}{c}2 \text { - } 5 \mathrm{~cm} \text { annual twig } \\
\text { elongation }\end{array}$ & $\begin{array}{c}<2 \mathrm{~cm} \text { annual twig } \\
\text { elongation }\end{array}$ \\
\hline Pest & $\begin{array}{c}\text { No insect or disease } \\
\text { problems }\end{array}$ & $\begin{array}{l}\text { Minor insect or } \\
\text { disease problems }\end{array}$ & $\begin{array}{l}\text { Minor insect \& } \\
\text { disease problems }\end{array}$ & $\begin{array}{l}\text { Serious disease or } \\
\text { insect problems }\end{array}$ & $\begin{array}{c}\text { Serious disease \& insect } \\
\text { problems }\end{array}$ \\
\hline Life & >50 years & 30 to 50 years & 20 to 30 years & 10 to 20 years & $<10$ years \\
\hline expectancy & & & & & \\
\hline
\end{tabular}

\subsection{Oak Ridge Traffic and Stream Data}

In order to determine which streets had the most traffic, traffic rates needed to be determined for each street. Traffic rates, measured as cars per day, where obtained through traffic records from the Tennessee Department of Transportation 2011 report for Oak Ridge East Anderson County (TDOT, 2011). Distance from street tree to the nearest stream was determined by using the points collected by the Garmin etrex 20 during the inventory at each street tree, ArcMap 10, and stream vector data from the USGS National Hydrography Dataset (ESRI, 2011; USDA/NRCS, 2012). To determine the distance of each street tree to the nearest stream, the Join function was used in ArcMap to join the streams polyline shapefile to the street tree inventory point shapefile. Joining the two shapefiles by location resulted in a point shapefile with the street tree attributes as well as the attributes of the closest stream and the distance of each tree to that stream.

\subsection{Soil Nutrients Analysis}

All soil samples were air dried and passed through a $250 \mu \mathrm{m}$ (60-mesh) sieve. Total elemental analysis was determined as described by Nadkarni (1984), using microwave oven digestion with modifications. Total elemental analysis of the digested soil samples was analyzed by inductively coupled atomic emission spectrometry (ICP). Exchangeable $\mathrm{Ca}, \mathrm{K}, \mathrm{Mg}, \mathrm{Pb}, \mathrm{Cd}, \mathrm{Mn}, \mathrm{Fe}, \mathrm{Zn}, \mathrm{Ni}$ and $\mathrm{Cu}$ were determined by extraction with $1 \mathrm{~N}$ ammonium acetate $\left(1 \mathrm{NH}_{4} \mathrm{OAc}, \mathrm{pH} 7.0\right)$. The $\mathrm{pH}$ of the $1 \mathrm{NH}_{4} \mathrm{OAc}$ was adjusted by adding concentrated ammonium hydroxide. Exchangeable were analyzed by ICP. Sodium saturation method $(\mathrm{pH} 7.0)$ was used to determine cation exchange capacity (CEC) (Chapman, 1965). The 1:1 method was used to measure $\mathrm{pH}$. An adaptation of Blake (1965) bulk density for gravelly soils was used to determine the bulk density by dividing each total dry weight (g) by the volume $\left(\mathrm{cm}^{3}\right)$ of each hole. Gravimetric soil moisture was attained by the difference between soil fresh weight (m) and oven dry weight (d) divided by d using the following equation: $\Theta g=m-d / d$.

\subsection{Soil Microbial Biomass Analysis}

The simultaneous chloroform fumigation extraction (sCFE) "slurry" method was adapted from Fierer (2003) for microbial biomass carbon (MBC) and microbial biomass nitrogen (MBN). To analyze total carbon and nitrogen a TOC-VCPH SHIMADZU (detection limit $0.1 \mathrm{ppm}$ ) was used. Microbial C biomass was determined using the following equation: 


$$
\mathrm{MBC}=\mathrm{EC} / \mathrm{kEC}
$$

where the chloroform-labile pool (EC) is the difference between $\mathrm{C}$ in the fumigated and non-fumigated extracts, and $\mathrm{kEC}$ is soil-specific and estimated as 0.45 (Beck et al., 1997). Microbial N biomass was determined using the following equation:

$$
\mathrm{MBN}=\mathrm{EN} / \mathrm{kEN}
$$

where the chloroform-liable $\mathrm{N}$ pool is the difference between $\mathrm{N}$ in the fumigated and non-fumigated extracts, and $\mathrm{kEN}$ is soil-specific and estimated as 0.54 (Brookes et al. 1985). MBC and MBN were expressed as $\mu \mathrm{g} \cdot \mathrm{N} \cdot \mathrm{g}^{-1}$. Soil carbon to nitrogen, microbial biomass carbon to nitrogen and microbial carbon to organic carbon ratios were calculated. To analyze total organic carbon the TOC by acidification/sparging method was used. To analyze total nitrogen a TNM-1 SHIMADZU unit was used (detection limit $0.1 \mathrm{ppm}$ ).

\subsection{Data Analysis}

A Pearson's two-tailed correlation coefficient in SPSS 21 was used to determine what soil biological, chemical and physical properties were correlated with microbial biomass carbon (MBC) and microbial biomass nitrogen (MBN) in the urban soils at street tree planting locations (IBM Corp. Released 2012). A Principal Components Analysis (PCA) in JMP Pro 10.0.2 was used to determine the soil properties that were the most heavily characterizing the urban soil of Oak Ridge, Tennessee $\left(\mathrm{JMP}^{\circledR}\right.$ (1989-2007), Version Pro 10.0.2). Multivariate Analysis of Variance (MANOVA) was used to measure the variance of different means of dependent variables (elemental concentrations, total $\mathrm{C}$, total known $\mathrm{N}$, soil $\mathrm{pH}$, bulk density, soil microbial biomass MBC and MBN, and soil water content) between the five streets. A one-way Analysis of Variance (ANOVA) using JMP Pro was used to determine the differences between seasons in MBC, MBN, soil water content, and $\mathrm{pH}$. A log10 transformation was used for the MBC and MBN data in order to satisfy the ANOVA assumption of normality. The $\log 10$ transformed means were then reverted to its original state by raising it as an exponent over ten: $10^{\wedge{ }^{\log 10}}$ (MBC or MBN). Levenne's test for unequal variance was done for all ANOVA's in order to meet ANOVA assumptions. All variables with standard deviation within five fold of each other were also considered to have met the equal variance assumption. A Pearson's two tailed correlation coefficient and the principal components from the PCA was used to investigate which urban environmental stressors were likely influencing street tree conditions and growth. Urban environmental stressors, elemental concentrations, soil $\mathrm{pH}$, bulk density, soil microbial biomass MBC and MBN, soil water content, tree distance from impervious surface, and distance from closest stream were independent variables that were tested for their influences on the dependent variables, tree condition score and growth.

\section{Results}

The number of street trees that were inventoried along the five main thoroughfares in Oak Ridge was 607, with 37 different species. The diameters ranged from $5.08 \mathrm{~cm}$ to $93.98 \mathrm{~cm}$ and the average diameter of the street trees was $30.3 \mathrm{~cm}$. The general street tree conditions showed 52\% (313 trees) as good, 30\% (185 trees) fair, 16\% (96 trees) poor, and $2 \%$ (13 trees) dead. The street tree ecosystems, as a whole, were predominately Acer rubrum (21.91\%) and Pyrus calleryana (19.93\%). The total diversity index for the five streets was $\mathrm{H}^{\prime}=1.39$. The diversity indices $\left(\mathrm{H}^{\prime}\right)$ of each street were Oak Ridge Turnpike 1.81, Lafayette 1.43, Illinois 1.85, Rutgers 1.12, and Tulane 0.75 .

Table 2 and Table 3 describe the physical, biological, chemical properties of the sampled soils and sites that were analyzed along the five main streets in Oak Ridge. The Pearson's two-tailed correlation matrix revealed several significant correlations between street tree soil biological, chemical and physical properties and site characteristics. Tree distance from impervious surface was significantly $(p<0.05)$ negatively correlated with Ca, $\mathrm{Co}, \mathrm{Mn} \mathrm{P}, \mathrm{S}, \mathrm{Sr}, \mathrm{Zn}, \mathrm{Pb}$, winter microbial biomass nitrogen (wMBN), and winter microbial biomass carbon (wMBC). Distance from impervious surface was also significantly $(p<0.05)$ positively correlated to K. Tree distance to the closest stream was significantly $(p<0.05)$ negatively correlated with tree distance from impervious surface, wMBN, bulk density, and $\mathrm{Zn}$. Significant $(p<0.05)$ positive correlations were found with winter gravimetric soil moisture (wGSM) and wMBN, wMBC, Ca, and Cr; whereas, wGSM was found to be significantly $(p<0.05)$ positively correlated with $\mathrm{Ba}, \mathrm{Ti}$, and tree crown width. Significant $(p<0.05)$ positive correla- 
Table 2. Soil biological, chemical and physical properties and site characteristics in Oak Ridge, TN street trees soil, $\mathrm{n}=136$. Bulk density $n=65$.

\begin{tabular}{|c|c|c|c|c|}
\hline & Min & Max & Mean & SE \\
\hline Tree distance from impervious surface (m) & 0.52 & 19.46 & 4.86 & 0.31 \\
\hline Tree distance from stream (m) & 11.46 & 630.18 & 245.35 & 13.60 \\
\hline Bulk density $\left(\mathrm{g} \cdot \mathrm{cm}^{-3}\right)$ & 0.43 & 2.11 & 1.33 & 0.03 \\
\hline Bulk density with rocks $\left(\mathrm{g} \cdot \mathrm{cm}^{-3}\right)$ & 0.43 & 3.21 & 1.46 & 0.04 \\
\hline Winter $\mathrm{pH}$ & 4.82 & 8.62 & 7.61 & 0.05 \\
\hline Spring $\mathrm{pH}$ & 5.28 & 8.17 & 7.27 & 0.04 \\
\hline Winter gravimetric soil moisture (\%) & 20.00 & 69.49 & 29.63 & 0.47 \\
\hline Spring gravimetric soil moisture (\%) & 8.45 & 43.47 & 23.08 & 0.51 \\
\hline Cation exchange capacity $\left(\mathrm{cmol} \cdot \mathrm{kg}^{-1}\right)$ & 1.43 & 10.40 & 4.88 & 0.13 \\
\hline \multicolumn{5}{|l|}{$\mathrm{ug} \cdot \mathrm{g}^{-1}$} \\
\hline Winter microbial biomass carbon & 3.74 & 279.18 & 54.20 & 3.54 \\
\hline Winter extractable organic carbon & 9.15 & 137.92 & 5.65 & 2.18 \\
\hline Winter total labile carbon & 20.01 & 417.10 & 104.50 & 4.83 \\
\hline Winter microbial biomass nitrogen & 0.07 & 53.17 & 9.81 & 0.74 \\
\hline Winter extractable organic nitrogen & 5.83 & 56.54 & 17.86 & 0.63 \\
\hline Winter total labile nitrogen & 8.33 & 109.71 & 27.65 & 1.20 \\
\hline Spring microbial biomass carbon & 1.08 & 291.20 & 38.69 & 4.20 \\
\hline Spring extractable organic carbon & 61.60 & 499.72 & 186.83 & 7.58 \\
\hline Spring total labile carbon & 72.36 & 564.82 & 225.80 & 9.00 \\
\hline Spring microbial biomass nitrogen & 0.44 & 39.06 & 7.61 & 0.73 \\
\hline Spring extractable organic nitrogen & 9.23 & 61.07 & 20.30 & 0.64 \\
\hline Spring total labile nitrogen & 12.56 & 75.66 & 27.97 & 1.00 \\
\hline "Extreme outliers were removed. & & & & \\
\hline
\end{tabular}

tions were found between wMBN and wGSM, Mg, Ni, P, S, Sr, and Zn. The wMBC was found to be significantly $(p<0.05)$ positively correlated to wGSM, Ca, Cr, Mg, Ni, S, Sr, Zn, and Pb; as well as negatively significantly correlated with Ba. Tree condition scores were significantly $(p<0.05)$ positively correlated with Ca, tree diameter, live crown ratios (LCR); likewise, tree condition scores were significantly $(p<0.05)$ negatively correlated with As.

Multivariate Analysis of Variance (MANOVA) was run to compare mean differences between street tree soils' biological, physical and chemical properties (Table 4). Illinois and Lafayette significantly $(p<0.05)$ differed from ORTP in MBC and MBN differed significantly $(p<0.05)$ on ORTP and Lafayette. Streets differed in chemical and physical composition between bulk density, wGSM, distance of tree from impervious surface, three macronutrients (K, P and S) and three micronutrients (Fe, Mn, and Zn) (Table 4). The only heavy metal that differed significantly between streets was Zn. Even though there was no significant difference between the busiest street (Illinois) and the least busy street (Tulane), the second busiest street (ORTP) did have significantly more $\mathrm{Zn}$ in the street tree planting soil than Lafayette. The wMBC and wMBN proved to not be lower on busier streets than less busy streets even though there were significant differences found between the streets. When comparing Illinois to Tulane for both wMBC and wMBN, both instances revealed no significant differences in microbial biomass.

One-way ANOVA tests for each seasonal variable showed multiple differences between the two seasons (Prob $>\mathrm{F}=<0.05^{*}$ ) (data not shown). Overall, the winter season had significantly higher MBC and MBN. The MBC in the winter had a mean of $54.20 \mathrm{ug} \cdot \mathrm{g}^{-1}$ while the street tree soil in the spring had a mean MBC of 38.69 $\mathrm{ug} \cdot \mathrm{g}^{-1}$. The wMBN had a mean of $9.81 \mathrm{ug} \cdot \mathrm{g}^{-1}$ and a spMBN of $7.61 \mathrm{ug} \cdot \mathrm{g}^{-1}$. Extractable organic carbon (EOC) and total labile carbon (TLC) were both significantly higher in the spring than the winter. EOC had mean spring concentration of $186.83 \mathrm{ug} \cdot \mathrm{g}^{-1}$ and the winter had a concentration of $50.65 \mathrm{ug} \cdot \mathrm{g}^{-1}$. TLC in the spring was at a mean concentration of $225.81 \mathrm{ug} \cdot \mathrm{g}^{-1}$. Extractable organic nitrogen (EON) differed significantly between the two seasons with a mean concentration of $20.30 \mathrm{ug} \cdot \mathrm{g}^{-1}$ in the spring and $17.86 \mathrm{ug} \cdot \mathrm{g}^{-1}$ in the winter. Total labile nitro- 
Table 3. Soil chemical properties in Oak Ridge, TN street tree soil, $\mathrm{n}=136$.

\begin{tabular}{|c|c|c|c|c|}
\hline & Min & Max & Mean & SE \\
\hline \multicolumn{5}{|l|}{ Analytes } \\
\hline Aluminum-Al & 17366.67 & 91966.67 & 49397.51 & 1154.64 \\
\hline Arsenic_-As & 0.7 & 46.72 & 6.22 & 0.49 \\
\hline Barium-Ba & 971.17 & 92966.67 & 9866.26 & 942.79 \\
\hline Calcium-Ca & 60.47 & 562.83 & 273.07 & 6.84 \\
\hline Cadmium-Cd & 0.18 & 2.83 & 1.04 & 0.04 \\
\hline Cobalt-Co & 4.5 & 34.9 & 14.57 & 0.47 \\
\hline Chromium-Cr & 16.2 & 171.38 & 42.48 & 1.30 \\
\hline Copper-Cu & 5.1 & 104.6 & 33.59 & 1.29 \\
\hline Iron-Fe & 10966.67 & 53966.67 & 27445.89 & 663.83 \\
\hline Potassium-K & 1536.67 & 29583.33 & 11328.44 & 363.91 \\
\hline Magnesium-Mg & 948.33 & 37716.67 & 4846.39 & 286.25 \\
\hline Manganese- - Mn & 65.52 & 4476.67 & 1032.86 & 64.38 \\
\hline Molybdenum-Mo & 0.63 & 20.38 & 3.24 & 0.22 \\
\hline Sodium—Na & 545.83 & 4591.67 & 2846.06 & 72.20 \\
\hline Nickel—Ni & 6.87 & 110.93 & 22.15 & 1.05 \\
\hline Phosphorus-P & 114.43 & 1148.33 & 460.11 & 18.25 \\
\hline Lead-Pb & 2.68 & 916.5 & 69.07 & 8.91 \\
\hline Sulfur-S & 70.83 & 853.67 & 359.71 & 10.96 \\
\hline Selenium—Se & 0.63 & 35.85 & 6.95 & 0.54 \\
\hline Strontium-Sr & 9.28 & 183.65 & 40.01 & 1.48 \\
\hline Titanium-Ti & 571.17 & 3450 & 1579.79 & 38.48 \\
\hline Zinc-Zn & 28.30 & 266.23 & 95.96 & 3.25 \\
\hline
\end{tabular}

*Analytes were determined for the winter sample and measured as $\mathrm{mg} \cdot \mathrm{kg}^{-1}$. ${ }^{*}$ Extreme outliers were removed.

Table 4. MANOVA results for street differences in mean soil and site biological, chemical, and physical properties of street tree ecosystems, $\mathrm{n}=136$. Bulk density $\mathrm{n}=65$.

\begin{tabular}{|c|c|c|c|c|c|c|c|c|}
\hline & \multicolumn{5}{|c|}{ Means by street } & \multirow[t]{2}{*}{ Min } & \multirow[t]{2}{*}{ Max } & \multirow[t]{2}{*}{ SE } \\
\hline & Illinois & Lafayette & ORTP & Rutgers & Tulane & & & \\
\hline Annual average daily traffic (cars/day) & 26736 & 17160 & 21077 & 11445 & 7032 & & & \\
\hline $\begin{array}{l}\text { Winter microbial biomass carbon } \\
\left(\text { ug } \cdot \mathrm{g}^{-1}\right)\end{array}$ & $38.33 b$ & $38.08 \mathrm{~b}$ & $71.26 \mathrm{a}$ & 47.36ab & $56.16 \mathrm{ab}$ & 3.74 & 279.18 & 3.54 \\
\hline $\begin{array}{l}\text { Winter microbial biomass nitrogen } \\
\qquad\left(\mathrm{ug} \cdot \mathrm{g}^{-1}\right)\end{array}$ & $8.46 \mathrm{ab}$ & $6.69 b$ & $12.35 \mathrm{a}$ & 7.16ab & $5.29 \mathrm{ab}$ & 3.74 & 279.18 & 0.74 \\
\hline $\begin{array}{l}\text { Tree distance from impervious } \\
\text { surface }(\mathrm{m})\end{array}$ & $5.20 \mathrm{ab}$ & $6.44 a$ & $3.74 \mathrm{~b}$ & 7.74a & 3.52ab & 0.52 & 19.51 & 0.31 \\
\hline Bulk density $\left(\mathrm{g} \cdot \mathrm{cm}^{-3}\right)$ & $1.42 \mathrm{a}$ & $1.36 \mathrm{ab}$ & $1.32 \mathrm{ab}$ & $1.03 \mathrm{~b}$ & $1.12 \mathrm{ab}$ & 0.43 & 2.11 & 0.03 \\
\hline Winter gravimetric soil moisture (\%) & $27.21 b$ & $27.24 \mathrm{~b}$ & $31.24 \mathrm{a}$ & $34.15 a$ & 28.94ab & 20.00 & 69.49 & 0.47 \\
\hline \multicolumn{9}{|l|}{ Analytes $\left(\mathrm{mg} \cdot \mathrm{kg}^{-1}\right)$} \\
\hline Iron-Fe & $27250.86 \mathrm{ab}$ & $23034.25 b$ & 29228.46a & $32936.25 a$ & $22556.25 \mathrm{ab}$ & 10966.67 & 53966.67 & 663.83 \\
\hline Potassium-K & 13811.23a & 13069.35ab & 9838.81c & 10152.08abc & 8009.17bc & 1536.67 & 29583.33 & 363.91 \\
\hline Manganese- - Mn & 994.64ab & $643.18 b$ & 1169.67a & 1188.88ab & 1741.42a & 65.52 & 4476.67 & 64.38 \\
\hline Phosphorus-P & 559.89a & $326.08 b$ & 472.10a & $546.90 \mathrm{a}$ & $454.00 \mathrm{ab}$ & 114.43 & 1148.33 & 18.25 \\
\hline Sulfur-S & $316.62 b$ & 332.11ab & 396.18a & $372.69 \mathrm{ab}$ & $236.76 \mathrm{ab}$ & 70.83 & 853.67 & 10.96 \\
\hline Zinc-Zn & 94.4abab & $74.32 \mathrm{~b}$ & 108.79a & 81.35ab & 91.69ab & 28.30 & 266.23 & 3.25 \\
\hline
\end{tabular}

"Letters within rows indicate significant difference in means at the 0.05 level. "Extreme outliers were removed. 
gen (TLN) did not differ seasonally. The GSM in the winter was also significantly higher than the spring with means of $29.63 \%$ water and $23.08 \%$. There was no difference in soil pH between seasons.

Tree condition score was not significantly correlated to physical or biological properties measured $(p<0.05)$. The physical soil properties and planting site characteristics (tree distance to impervious surface and tree distance to closest stream) were found to have no correlation to street tree performance. However, street tree condition score was significantly positively and negatively correlated to Ca and As, respectively (data not shown). Annual twig elongation (growth) was significantly and positively correlated with Ca as well as spring gravimetric soil moisture (spGSM) (data not shown). Despite the lack of correlation between site properties and tree condition and growth, there were high concentrations of heavy metals other than As found in the street tree soils (Table 3). Principal component analysis (PCA) produced a total of thirty-five components. The first eleven components accounted for over seventy-three percent of the variance among the variable (data not shown). The eleven components were then used as variables for Pearson's Correlation with tree condition score and tree growth. None of the principal components were significantly correlated to tree score or growth. The biplot of the first two components, however, show that the data was heavily loaded on by several elements, wMBC, wMBN, and distance to impervious surface (data not shown). Also, the score plots with, represented by general condition show more poor trees grouped closer to the origin and extending into quadrats 1 and 3 (data not shown).

\section{Discussion}

The current status of Oak Ridge's street trees seems to be in fairly good standing if Emerald Ash Borer (EAB) or walnut twig beetle (the vector for TCD) should hit since the street tree ecosystems are comprised of only 2.31\% Fraxinus pennsylvanica and $0.33 \%$ Juglans nigra (Table 2). However, if the tree diversity was higher in Oak Ridge, herbivory from EAB and the walnut twig beetle could be deterred and result in healthier street tree ecosystems (Jactel and Brockerhoff, 2007). The street tree diversity in Oak Ridge was also found to be lower than forests of surrounding rural areas (Jean-Philippe, unpublished data). The street tree inventory of the five main thoroughfares revealed a composition of being nearly 22\% Acer rubrum and 20\% Pyrus calleryana; therefore, should disease or pests strike one of those two species, the Oak Ridge urban forest could potentially experience drastic losses in ecosystem services. According to the 10:20:30 rule, a street tree population should not be composed of more than $10 \%$ of a single species, $20 \%$ of a single genus, or $30 \%$ of a single family (Subburayalu and Sydnor, 2012). Judging by the 10:20:30 guideline, Oak Ridge street tree ecosystems' diversity falls short of that accepted diversity parameter. The guideline was created to prevent widespread destruction in the event of disease outbreak. The overabundance of Pyrus calleryana also presents an existing problem without pests or disease. Pyrus calleryana "Bradford", which is common in Oak Ridge as well as other cities, is known to have poor branch attachments due to crotch formations; thereby making these trees susceptible to branch loss, splitting from wind or storm damage, and an overall shorter lifespan (Dirr, 1990).

The negative correlation with As and tree condition could be an indication that increased amounts of As in Oak Ridge urban soil could harmful to the street trees. Arsenic has been found to inhibit root elongation and could therefore be influencing tree performance (Song et al., 2006). The positive correlation between tree condition and growth with Ca indicate that the street trees tend to have better performance and growth on sites with higher amounts of $\mathrm{Ca}$. Street trees that are receiving higher amounts of $\mathrm{Ca}$ could be in better condition and growing more because $\mathrm{Ca}$ is vital for the synthesis of cell walls in plants and cell membrane stabilization (Eklund and Eliasson, 1990; Fromm, 2010). The positive correlation with growth and spGSM could be an insight that some street trees in Oak Ridge during the spring had limited water available in their root zones; therefore, growth may have been limited to trees that had less soil moisture at their planting sites. Water availability to street tree is an issue that not only faces urban forest managers, but has also been thoroughly investigated. Excess water as well as drought can have detrimental impacts on urban tree performance (Saebo et al., 2003; Nielson et al., 2007). The positive correlation with tree growth and spGSM in Oak Ridge's soils may suggest that lack of water may be an issue for the street tree ecosystems. Although these correlations do not indicate causation, this does open doors for more research and possible management directives to be taken. Oak Ridge in particular, may benefit by selecting street trees to plant for dryer sites that are more drought tolerant (Whitlow et al., 1992). Also, further investigation of soil chemicals on tree physiological properties would offer greater insight to the impacts of urban soils on tree growth and condition.

The interactions between site properties with tree condition and growth were further investigated by using a 
Principal Components Analysis (PCA). Eleven principal components, with eigenvalues over one, accounted for over seventy-three percent of the variance within the data. Since it took eleven components to explain seventy-three percent of the variance within the data, it is apparent that the street tree ecosystem soil in Oak Ridge is variable in its characteristics. In Oak Ridge, the soil and site characteristics that greatly influenced the variance of the data were the winter microbial biomass concentration, distance to impervious surface, and multiple soil chemical concentrations ( $\mathrm{Al}, \mathrm{Fe}, \mathrm{P}, \mathrm{Cr}, \mathrm{Zn}, \mathrm{Sr}, \mathrm{S}$, and $\mathrm{Ca}$ ). When plotting the sample plots by tree score on the first two component axes, there were no apparent groupings based on better tree performance or worse tree performance. A similar study by Scharenbroch and Catania (2012) that used the same tree score method, found that soil texture and $\mathrm{pH}$ correlated with tree conditions while tree growth was correlated to wet-aggregate stability, bulk density, $\mathrm{pH}$, soil organic matter (SOM), and particulate organic matter (POM). Their findings seemed to imply that the physical properties of soils impacted the tree conditions and growth. Whereas, Cekestere and Osvalde (2013) found that street and park trees that were in poorer condition were growing in soils that were high in $\mathrm{Na}, \mathrm{Cl}$, and $\mathrm{Mg}$; and low in $\mathrm{K}, \mathrm{Fe}, \mathrm{Cu}, \mathrm{B}$. Therefore, chemical concentrations in the latter study were moreover what weighed the heaviest on the ability of street trees to perform.

The soil analyses indicated that urbanization has impacted Oak Ridge's urban soil biologically, chemically, and physically. Compared to a concurrent study done in area rural forests, Oak Ridge street tree soils had higher $\mathrm{Ca}, \mathrm{Mg}, \mathrm{Cu}, \mathrm{Zn}, \mathrm{Pb}, \mathrm{MBN}, \mathrm{MBC}$, and CEC; whereas, Oak Ridge street tree soils were lower in Mn, Na, and bulk density (Jean-Philippe, unpublished data). The initial correlation matrix showed that there were many soil and site characteristics that were correlated with one another. The correlation matrix also resulted in multiple significant correlations between distance to impervious surfaces, such as concrete, and several soil properties. The $\mathrm{pH}$ of Oak Ridge's street tree soil was not among the variables that correlated with distance to impervious surface; whereas $\mathrm{pH}$ has been found in other areas to increase the closer the distance to roadways (Trammell et al., 2011). Trammell et al. (2011) also found that $\mathrm{Cd}, \mathrm{Cu}, \mathrm{Cr}, \mathrm{Ni}, \mathrm{Zn}$, and $\mathrm{Pb}$ all decreased as distance to interstate increased. This same trend was found in Oak Ridge with Ca, Co, Mn, P, Pb, Sr, S, and Zn. The analyte, K, was the only element that had increasing concentrations as distances to impervious surfaces increased. One reason this trend could be more pronounced in Oak Ridge than the study conducted by Trammell et al. (2011) is that the soil samples for Oak Ridge were taken within the center of the city rather than in forests along the urban interstates. Therefore, Oak Ridge's urban soils could be subject to more direct anthropogenic inputs. In urban areas, Ca often originates from building materials such as concrete which is incorporated into the soil formation (Orsini et al., 1986). Therefore, it makes sense that Oak Ridge's street tree soils exhibit the pattern of having higher concentrations of Ca closer to roadways. Furthermore, since Ca can promote alkalinization, the more acidic soils that were found closer to impervious surfaces suggest that there may be inputs, such as fertilizers, that are preventing the soils from being more alkaline (Cekstere and Osvalde, 2013). Fertilizers could also explain the higher concentrations of P closer to impervious surfaces. Pouyat et al. (2007) proposed that the P and K found Baltimore, Maryland urban soils were likely from lawn fertilizers. K, however, had an opposite trend than $\mathrm{P}$ in regards to the impervious surfaces in Oak Ridge. The higher amounts of $\mathrm{Zn}$ closer to roadways could be from dust of deteriorated vehicle parts, such as tires, that contain Zn (Cekstere and Osvalde, 2013). Some motor fuels have anti-knock agents that contain Mn; thereby, offering a possible explanation for the higher Mn concentrations found closer to the roadways in Oak Ridge (Zayed et al., 1999). Furthermore, decades of Pb based fuels being used for decades within the city likely caused the street tree ecosystem soils to have greater $\mathrm{Pb}$ concentrations than the rural forest soils (Mielke and Reagan, 1998). Both wMBC and wMBN were significantly and negatively correlated with distance to impervious surface. This result could be showing the potential of impervious surface to promote more soil microbial biomass. A soil $\mathrm{pH}$ near neutral (6-7) is optimal for most soil microbes; therefore, the higher $\mathrm{pH}$ and microbial biomass found closer to impervious surfaces could mean that alkaline adapted microbes, such as some cyanobacteria, are more prevalent closer to roadways than other microbes (Sylvia et al., 2005). Further investigation of microbial ecology in street tree soil would provide better understanding for the types of microbes and their functions along roadways.

The impacts of urbanization on the street tree ecosystem soils in Oak Ridge can be seen in the properties and the distribution of the soils along roadways. Firstly, the soils along the roadways biologically, chemically, and physically differed between certain streets (Table 4). Those differences in soil composition demonstrate that urban soils are heterogeneous in their distribution due to anthropogenic influences such as construction, soil sealing from impervious surfaces, fill soil, and pollutants (Vasenev et al., 2013; L. Yang et al., 2014). Both wMBC and wMBN were significantly higher along ORTP than Lafayette. Lafayette had significantly less soil moisture 
(wGSM) than ORTP, so it could also be that the amount of soil moisture along Lafayette in the winter could be the factor that is preventing higher amounts of microbial biomass. Another factor that could have driven the lower microbial biomass along Lafayette is the abundance of Eastern white pine (Pinus strobus) which constitutes $36 \%$ of the species found on that street. Bauhus et al. (1998) found that microbial biomass nitrogen was significantly less under conifers when compared to broadleaf deciduous trees; therefore, the Eastern white pines along Lafayette could be suppressing the soil microbial community. The wMBC was also significantly higher in soils along ORTP than Illinois. Illinois also had significantly less wGSM than ORTP; therefore, the higher amount of soil moisture along ORTP soils could likely be the reason for more microbial biomass. The second busiest road is ORTP; therefore, it seems that higher traffic rates on ORTP did not negatively impact the microbial biomass. It is likely that other factors such as water, vegetation, impervious surfaces, and direct soil disturbances have a greater impact on the soil microbial community than the amount of traffic a roadway receives. The distance of trees to impervious surface was lowest on Tulane and almost the same as ORTP. The three largest and busiest streets (Illinois, ORTP, and Lafayette) had the highest bulk densities, but statistically only Illinois was significantly higher than Rutgers. The higher bulk densities along Illinois could be because it receives more traffic than Rutgers and also has had a more recent history of construction activities. From a hydrological perspective, the wGSM was significantly higher along ORTP and Rutgers. Trees growing along those roadways may not be getting sufficient water or in some cases too much water.

Chemically, certain the streets differed significantly from each other in Fe, K, Mn, P, S, and Zn concentrations. Although Zn did not differ between Illinois and Tulane (busiest and least busy street), a significant difference was found between ORTP (21077 cars/day) and Lafayette (17160 cars/day) (Table 4). Overall, ORTP is more intensely developed than Lafayette, Rutgers, and Tulane. Sources for $\mathrm{Zn}$ have been found to be decaying automobile parts (especially tire debris), municipal sludge's, and atmospheric deposition (Smolders and Degryse, 2002; Schrader, 1992; Olid et al., 2010). It is likely that the amount of development on ORTP and the amount automobile debris could be the reason for the higher concentrations of Zn than in street tree ecosystem soils along Lafayette. Again with Mn, the same trend can be found, ORTP is significantly higher than Lafayette. Another study that investigated soil properties and traffic densities along interstates also found that the amount of traffic did not explain variation in soil characteristics (Trammell et al., 2011). Pouyat et al. (1991) found that soils closer to the city exhibit higher concentrations heavy metals than soils further away. This could be a characteristic of Oak Ridge's soil environment, that instead of proximity to city center, heavier traffic rates are the culprits of higher elemental concentrations in the soils. Lafayette runs along the outer border of Oak Ridge and has not been as developed by large businesses, stores, or facilities; therefore, allowing less accumulation of trace metals from anthropogenic sources. The differences found in K, P, and S concentration are likely from areas getting more fertilizers for lawn care purposes. ORTP and Lafayette still differed significantly for analytes K and P; therefore, soils along roadways that are more intensely developed could be subject to higher nutrient concentrations. S, although not statistically significant, demonstrated the trend of ORTP having higher concentration than Lafayette as well. Overall, the impacts of urbanization on the roadside soil environment determine by two factors; impervious surfaces altering soil properties and processes, and the location of the roadways in the city rather than the amount of traffic.

The winter soil samples showed higher concentrations of MBC and MBN than the spring as well as significantly lower concentrations of EOC, TLC, and EON. Ros et al. (2009) found that EON was significantly higher in the spring than the winter season which was due to increased soil moisture and temperature that promoted soil microbial activity. The higher EON in the spring in Oak Ridge, along with the significantly less MBN in the spring, shows that as the seasons change the soil microbes were immobilizing soil nutrients into labile organic matter. Both EOC and TLC were significantly greater in the spring which also shows that the MBC was immobilizing nutrients into labile organic matter. These results demonstrate that even though the microbes were acting as a source for soil nutrients, they were allocating them into temporary immobilized pools of labile $\mathrm{C}$ and $\mathrm{N}$. Ectomycorrhizae and some plants are able to utilize labile organic nutrients from the soil organic matter (SOM) such as EON, EOC, and TLN (Van Der Heijerdan, 2008). Since the soil samples were taken before the street trees' buds broke, the soil nutrients may have been held immobile long enough in their different organic forms in order to be allocated to the tree roots rather than lost to the environment. The winter also had wetter soils than the spring, indicated by the significant difference in GSM. Soil moisture and temperature is known to be essential for soil microorganisms and their functioning (Sylvia et al., 2005). Therefore, it makes sense that the season with the most soil moisture would harbor the most MBC and MBN. A study conducted on forest soils in a mixed 
oak ecosystem in India found that the soil microbial biomass (C \& N) was not only higher in the wetter months, but that the winter season had lower soil microbial biomass (C \& N) than the spring months (Devi and Yadava, 2006). However, since the spring soil were dryer than the winter soils in Oak Ridge, then the soil microbial biomass seemed to have been impacted by the lack of moisture. The lack of precipitation during the spring sample period in Oak Ridge could have been the factor that led to less MBC and MBN. Devi and Yadava (2006) also suggest that the higher microbial $\mathrm{N}$ in the wetter periods could be a mechanism for conserving nutrients during times when losses are likely. Also, the decrease in MBN during from winter to spring could mean that the microbes are not acting as a sink for nutrients. Tessier and Raynal (2003) had a similar finding; the microbes were acting as a source and the understory vegetation was an $\mathrm{N}$ sink during the change from winter to spring when nutrient losses are high. In the case of Oak Ridge's urban forest, this could mean that nutrients are being lost (leached out or volatilized) since there is little to no understory along the street tree plantings. The SOM in Oak Ridge street tree ecosystem soils acted as a temporary sink for the soil nutrients until the trees were ready to have nutrients allocated to them. Therefore, the labile organic $\mathrm{C}$ and $\mathrm{N}$ served as an alternative sink in the street tree ecosystems since they lack native understory plant species. The predominant vegetation along the roadsides, other than the street trees, is turfgrass. Lawns have been found to exhibit greater $\mathrm{N}$ retention than forests; therefore, in order to fully understand the nutrient losses and storage from winter to spring, the $\mathrm{C}$ and $\mathrm{N}$ in the grass that constitutes the understory of the roadsides must also be tested (Raciti et al., 2008).

\section{Conclusion}

When determining the impacts of land-use change on urban soil and site biological, chemical, and physical properties and nutrient dynamics within street tree ecosystems, it was found that Oak Ridge street tree ecosystems differed. Streets with greater street tree diversity overall did not harbor more soil microbial biomass. The most diverse street, Illinois, was one of the lowest streets in wMBC. There were differences found between two other less diverse streets and ORTP, the second most diverse street. However, this finding does not fully support a relationship between street tree diversity and soil microbial biomass. These findings do show that specific street tree species in abundance could influence the soil microbial biomass rather than total tree diversity. The seasonal variation of $\mathrm{C}$ and $\mathrm{N}$ within street tree ecosystems indicates that even though there is a lack of native understory plants, street tree ecosystems are not experiencing significant nutrient losses from winter to spring. Even though MBC and MBN were significantly less in the spring than that in the winter, the higher levels of EOC, TLC, and EON in the early spring show that the nutrients are being temporarily immobilized into labile forms of $\mathrm{C}$ and $\mathrm{N}$ that will likely be a nutrient source for the street trees.

Busier streets did not seem to harbor greater amounts of heavy metals than less busy streets. Likewise, the amount of traffic did not seem to inhibit the soil microbial biomass; instead the busiest street had the highest amount of soil microbial biomass. Bulk density also was not higher along street that received more traffic. Proximity to the center could be a greater factor than the actual amount of heavy metals and microbes than the traffic density of the street trees. Also, more management such as lawn fertilization along certain roadways could be a greater influence than traffic amounts.

\section{Acknowledgements}

Financial support for this research was provided by the Department of Forestry, Wildlife and Fisheries at the University of Tennessee, Knoxville (UTK).Special thanks to the City of Oak Ridge, TN for access to street tree study sites.

\section{References}

Bauhus, J., Pare, D., \& Cote, L. (1998). Effects of Tree Species, Stand Age and Soil Type on Soil Microbial Biomass and Its Activity in a Southern Boreal Forest. Soil Biology and Biochemistry, 30, 1077-1089. http://dx.doi.org/10.1016/S0038-0717(97)00213-7

Beck, T., Joergensen, R. G., Kandeler, E., Makeschin, F., Nuss, E., Oberholzer, H. R., \& Scheu, S. (1997). An Inter-Laboratory Comparison of Ten Different Ways of Measuring Soil Microbial Biomass C. Soil Biology and Biochemistry, 29, 1023-1032. http://dx.doi.org/10.1016/S0038-0717(97)00030-8

Blake, G. R. (1965). Bulk Density in Methods of Soil Analysis. Agronomy, No. 9, Part 1, C. A. Black, 374-390.

Brookes, P. C., Landman, A., Pruden, G., \& Jenkinson, D. S. (1985). Chloroform Fumigation and the Release of Soil Nitro- 
gen: A Rapid Direct Extraction Method to Measure Microbial Biomass Nitrogen in Soil. Soil Biology and Biochemistry, 17, 837-842. http://dx.doi.org/10.1016/0038-0717(85)90144-0

Chapman, H. D. (1965). Cation-Exchange Capacity. In C. A. Black et al. (Eds.), Methods of Soil Analysis, Part 2, Chemical and Microbiological Properties (pp. 891-901). Agronomy, No. 9, Madison, WI: ASA.

Devi, N. B., \& Yadava, P. S. (2006). Seasonal Dynamics in Soil Microbial Biomass C, N, and P in a Mixed-Oak Forest Ecosystem of Manipur, North-East India. Applied Soil Ecology, 31, 220-227.

http://dx.doi.org/10.1016/j.apsoil.2005.05.005

Dirr, M. A. (1990). Manual of Woody Landscape Plants. Stipes, Champaign, IL, 674-683.

DOE (2013). Y-12 History. 14 January 2013. http://www.y12.doe.gov/about/history/

Eklund, L., \& Eliasson, L. (1990). Effects of Calcium Ion Concentration on Cell Wall Synthesis. Journal of Experimental Botany, 41, 863-867. http://dx.doi.org/10.1093/jxb/41.7.863

ESRI (2011). Arc GIS Desktop: Release 10. Redlands, CA: Environmental Systems Research Institute.

Fierer (2003). Stress Ecology and the Dynamics of Microbial Communities and Processes in Soil. Oakland, CA: University of California, $226 \mathrm{p}$.

Fromm, J. (2010). Wood Formation of Trees in Relation to Potassium and Calcium Nutrition. Tree Physiology, 30, 11401147. http://dx.doi.org/10.1093/treephys/tpq024

IBM Corp. Released (2012). IBM SPSS Statistics for Windows, Version 21.0. Armonk, NY: IBM Corp.

Jactel, H., \& Brockerhoff, B. G. (2007). Tree Diversity Reduces Herbivory by Forest Insects. Ecology Letters, 10, 835-848. http://dx.doi.org/10.1111/j.1461-0248.2007.01073.x

Jean-Philippe, S. R., Franklin, J. A., Buckley, D. S., \& Hughes, K. A. (2011). The Effect of Mercury Contamination on Trees and Their Mycorrhizal Fungi. Environmental Pollution, 159, 2733-2739. http://dx.doi.org/10.1016/j.envpol.2011.05.017

Jean-Philippe, S. R., Reichert, B. L., Turnbull, T., Schaeffer, S., \& Thompson-Adkins, M. M. (Unpublished Data). Woody Vegetation and Soil Microbial Nitrogen and Carbon along an Urban-to-Rural Gradient.

JMP ${ }^{\circledR}(1989-2007)$. Version Pro 10.0.2. Cary, NC: SAS Institute Inc.

Mielke, H. W., \& Reagan, P. L. (1998). Soil Is an Important Pathway of Human Lead Exposure. Environmental Health Perspectives, 106, 217-229. http://dx.doi.org/10.1289/ehp.98106s1217

Nadkarni, R. A. (1984). Applications of Microwave Oven Sample Dissolution in Analysis. Analytical Chemistry, 56, 22332237. http://dx.doi.org/10.1021/ac00276a056

Nielson, C. N., Buhler, O., \& Kristoffersen, P. (2007). Soil Water Dynamics and Growth of Street and Park Trees. Arboriculture \& Urban Forestry, 33, 231-245.

NOAA (2014). Oak Ridge Climate Normals and Records. Morristown, TN: National Weather Service Weather Forecast Office. http://www.srh.noaa.gov/mrx/?n=oqtclimate

Olid, C., Garcia-Orellana, J., Martinez-Cortizas, A., Masque, P., Peiteado-Varela, E., \& Sanchez-Cabeza, J. (2010). Multiple Site Study of Recent Atmospheric Metal (Pb, Zn and $\mathrm{Cu}$ ) Deposition in the NW Iberian Peninsula Using Peat Cores. Science of the Total Environment, 408, 5540-5549. http://dx.doi.org/10.1016/j.scitotenv.2010.07.058

Orsini, C. Q., Tabacniks, M. H., Artaxo, P., Andrade, M. F., \& Kerr, A. S. (1986). Characteristics of Fine and Coarse Particles of Natural and Urban Aerosols of Brazil. Atmospheric Environment, 20, 2259-2269. http://dx.doi.org/10.1016/0004-6981(86)90316-1

Pouyat, R. V., \& McDonnell, M. J. (1991). Heavy Metal Accumulations in Forest Soils along an Urban-Rural Gradient in Southeastern New York, USA. Water, Air, and Soil Pollution, 57-58, 797-807. http://dx.doi.org/10.1007/BF00282943

Pouyat, R. V., Yesilonis, I. D., Russell-Anelli, J., \& Neerchal, N. K. (2007). Soil Chemical and Physical Properties That Differentiate Urban Land-Use and Cover Types. Soil and Water Management and Conservation, 71, 1010-1019.

Raciti, S. M., Groffman, P. M., \& Fahey, T. J. (2008). Nitrogen Retention in Urban Lawns and Forests. Ecological Applications, 18, 1615-1626. http://dx.doi.org/10.1890/07-1062.1

Renewable Resources Evaluation Research Work Unit (1982). Resource Bulletin SO-87. New Orleans Louisiana: U.S. Department of Agriculture, Forest Service, Southern Forest Experiment Station. 24 p.

http://www.srs.fs.fed.us/pubs/1980\#sthash.GYBa7fma.dpuf

Resen, W. (2010). The Secret City: Oak Ridge, Tennessee. The Observer News. www.theobservernews.com

Ros, G. H., Hoffland, E., Kissel, C. V., \& Temminghoff, E. J. M. (2009). Extractable and Dissolved Soil Organic NitrogenA Quantitative Assessment. Soil Biology and Biochemistry, 41, 1029-1039.

http://dx.doi.org/10.1016/j.soilbio.2009.01.011

Saebo, A., Benedikz, T., \& Randrup, T. B. (2003). Selection of Trees for Urban Forestry in Nordic Countries. Urban Fore- 
stry and Urban Greening, 2, 101-114. http://dx.doi.org/10.1078/1618-8667-00027

Scharenbroch and Catania (2012). Soil Quality Attributes as Indicators of Urban Tree Performance. Arboriculture and Urban Forestry, 38, 214-228.

Schrader, S. (1992). Energy-Dispersive X-Ray Microanalysis of the Calciferous Glands of Lumbricus terrestris L. (Oligochaeta) Contaminated with Heavy Metals. Soil Biology and Biochemistry, 24, 1755-1759. http://dx.doi.org/10.1016/0038-0717(92)90183-X

Shannon, C. E., \& Weaver, W. (1949). The Mathematical Theory of Communication. Urbana, IL: The University of Illinois Press, 1-117.

Smolders, E., \& Degryse, F. (2002). Fate and Effect of Zinc from Tire Debris in Soil. Environmental Science and Technology, 36, 3706-3710.

Song, J., Zhao, F. J., McGrath, S. P., \& Luo, Y. M. (2006). Influence of Soil Properties and Aging on Arsenic Phytotoxicity. Environmental Toxicology and Chemistry, 25, 1663-1670. http://dx.doi.org/10.1897/05-480R2.1

Subburayalu, S., \& Sydnor, T. D. (2012). Assessing Street Tree Diversity in Four Ohio Communities Using the Weighted Simpson Index. Landscape and Urban Planning, 106, 44-50. http://dx.doi.org/10.1016/j.landurbplan.2012.02.004

Sylvia, D. M., Hartel, P. G., Fuhrmann, J. J., \& Zuberer, D. A. (2005). Principles and Applications of Soil Microbiology (2nd ed.). Upper Saddle River, NJ: Prentice Hall.

TDOT (2011). 2011 Traffic Map, Oak Ridge East Anderson County Tennessee. Tennessee Department of Transportation Long Range and Project Planning Divisions, US Department of Transportation Federal Highway Administration.

Tessier, J. T., \& Raynal, D. J. (2003). Vernal Nitrogen and Phosphorus Retention by Forest Understory Vegetation and Soil Microbes. Plant and Soil, 256, 443-453. http://dx.doi.org/10.1023/A:1026163313038

Trammell, T. L. E., Schneid, B. P., \& Carreiro, M. M. (2011). Forest Soils Adjacent to Urban Interstates: Soil Physical and Chemical Properties, Heavy Metals, Disturbance Legacies and Relationships with Woody Vegetation. Urban Ecosystem, 14, 525-552. http://dx.doi.org/10.1007/s11252-011-0194-3

USDA (1981). Soil Survey of Anderson County, Tennessee. USDA Soil Conservation Service and Tennessee Agricultural Experiment Station.

Van Der Heijerdan, M. G. A., Bardgett, R. D., \& Van Straalen, N. M. (2008). The Unseen Majority: Soil Microbes as Drivers of Plant Diversity and Productivity in Terrestrial Ecosystems. Ecology Letters, 11, 296-310.

http://dx.doi.org/10.1111/j.1461-0248.2007.01139.x

Vasenev, V. I., Stoorvogel, J. J., \& Vasenev, I. I., (2013). Urban Soil Organic Carbon and Its Spatial Heterogeneity in Comparison with Natural and Agricultural Areas in the Moscow Region. Catena, 107, 96-102. http://dx.doi.org/10.1016/j.catena.2013.02.009

Whitlow, T. H., Bassuk, N. L., \& Reichert, D. L. (1992). A 3-Year Study of Water Relations of Urban Street Trees. Journal of Applied Ecology, 29, 436-450. http://dx.doi.org/10.2307/2404512

Yang, L. Y., Li, Y., Peng, K., \& Wu, S. T. (2014). Nutrients and Heavy Metals in Urban Soils under Different Green Space Types in Anji, China. Catena, 115, 39-46.

Zayed, J., Pitre, J., Rivard, M., \& Loranger, S. (1999). Evaluation of Pollutant Emissions Related to the Use of MMT in Gasoline. Water, Air, and Soil Pollution, 109, 137-145. http://dx.doi.org/10.1023/A:1005056211891 
Scientific Research Publishing (SCIRP) is one of the largest Open Access journal publishers. It is currently publishing more than 200 open access, online, peer-reviewed journals covering a wide range of academic disciplines. SCIRP serves the worldwide academic communities and contributes to the progress and application of science with its publication.

Other selected journals from SCIRP are listed as below. Submit your manuscript to us via either submit@scirp.org or Online Submission Portal.
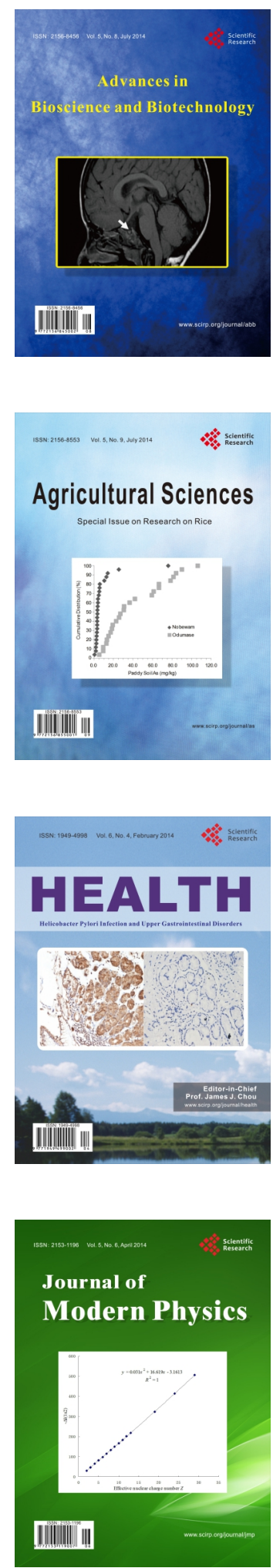
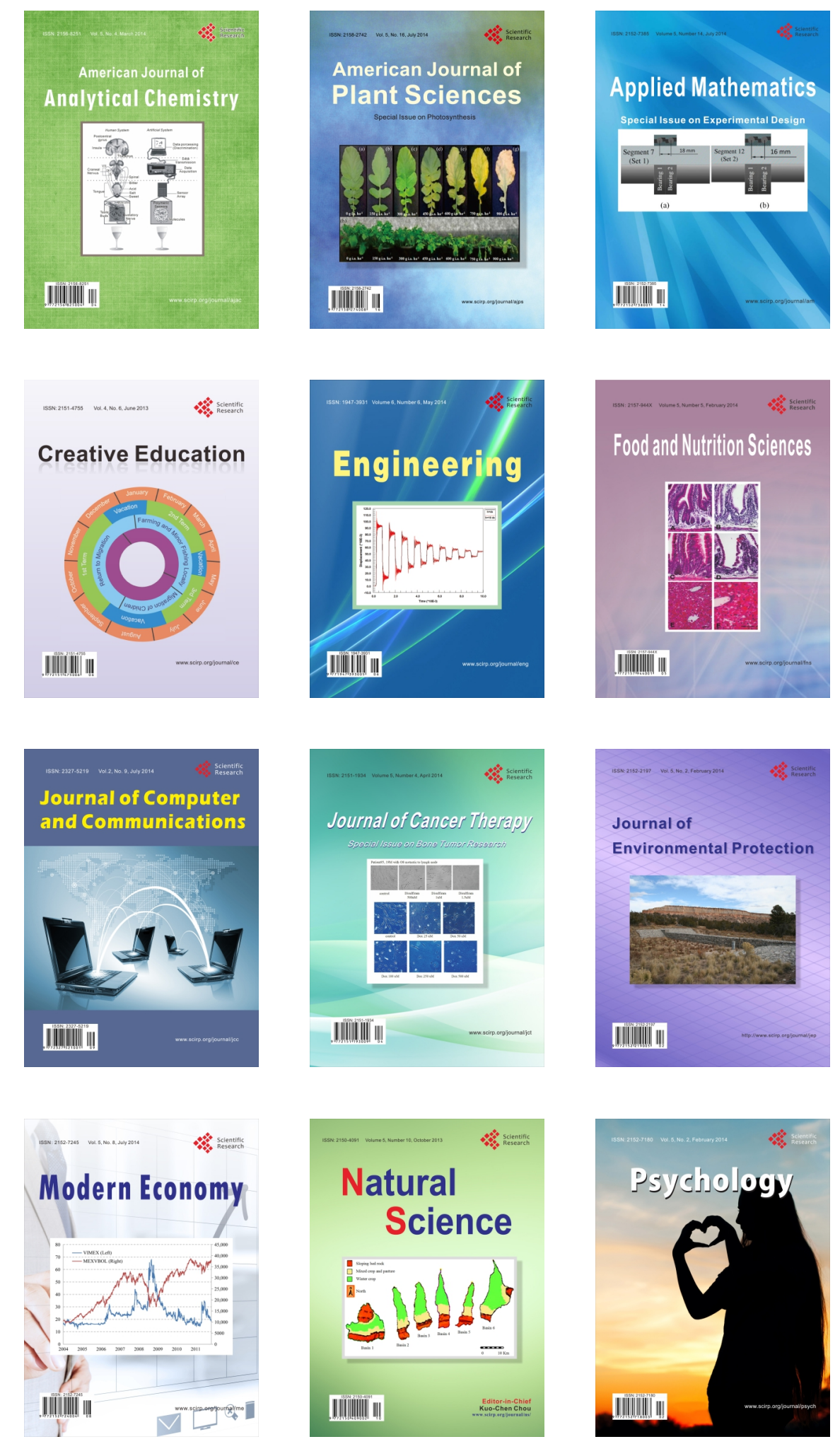